\title{
Pozzolanic Reactivity and the Influence of Rice Husk Ash on Early-Age Autogenous Shrinkage of Concrete
}

\author{
Muhammad Nasir Amin ${ }^{1 *}$, Syed Hissan ${ }^{2}$, Khan Shahzada ${ }^{2}$, Kaffayatullah Khan ${ }^{1}$ and \\ Tayyaba Bibi ${ }^{2}$ \\ ${ }^{1}$ Department of Civil and Environmental Engineering, College of Engineering, King Faisal University (KFU), Al-Hofuf, \\ Saudi Arabia, ${ }^{2}$ Department of Civil Engineering, University of Engineering and Technology (UET), Peshawar, Pakistan
}

\section{OPEN ACCESS}

Edited by: Xiangming Zhou,

Brunel University London,

United Kingdom

Reviewed by: lonut Ovidiu Toma

Gheorghe Asachi Technical University

of laşi, Romania Antonio Caggiano,

Darmstadt University of

Technology, Germany

*Correspondence:

Muhammad Nasir Amin mgadir@kfu.edu.sa

Specialty section: This article was submitted to

Structural Materials,

a section of the journal

Frontiers in Materials

Received: 11 April 2019

Accepted: 13 June 2019

Published: 02 July 2019

Citation:

Amin MN, Hissan S, Shahzada K, Khan K and Bibi T (2019) Pozzolanic Reactivity and the Influence of Rice Husk Ash on Early-Age Autogenous Shrinkage of Concrete. Front. Mater. 6:150. doi: 10.3389/fmats.2019.00150
In this study, the role of a locally available rice husk ash (RHA) in reducing early-age shrinkage of high performance concrete (HPC) after evaluating its pozzolanic reactivity was evaluated. The X-ray diffraction (XRD) and energy dispersive $\mathrm{X}$-ray (EDX) analyses were performed after burning rice husk to 700 and $950^{\circ} \mathrm{C}$. Presence of relatively high deposits of amorphous siliceous phases in $\mathrm{RHA}$ at $700^{\circ} \mathrm{C}$ indicated its pozzolanic potential. Subsequently, this RHA was ground to desired fineness, followed by sieving through sieve No. 200. Eventually, the fine RHA was used as a substitute of cement in different percentages $(10,15$, and $20 \%$ ) to evaluate its influence in mitigating autogenous shrinkage in concrete. Prismatic concrete beams $(100 \times 100 \times 800 \mathrm{~mm})$ were cast to measure autogenous shrinkage along with cylinders (150 mm dia. x $300 \mathrm{~mm}$ height) to test compressive strength of concrete. The results indicated a slight increase in compression strength with addition of 10\% RHA, which however, reversed and slightly reduced in concretes containing 15 and 20\% RHA. Unlike strength results, the trend of autogenous shrinkage was rather uniform as the rate as well as the amount of early-age autogenous shrinkage continued to decrease with increasing percentage of $\mathrm{RHA}$. Moreover, despite of reduced rate during first $24 \mathrm{~h}$, thereafter, the effect of $20 \% \mathrm{RHA}$ on further reduction of autogenous shrinkage was insignificant and ended up only slightly lesser than the 15\% RHA concrete at 7 days. Finally, the control cement sand mortar and mortar containing $15 \%$ RHA were cast to further validate the pozzolanic reactivity of RHA through scanning electron microscopy (SEM), EDX, and thermogravimetric analysis (TGA) tests. An observation of reduced amount of calcium hydroxide $\left(\mathrm{Ca}(\mathrm{OH})_{2}\right)$ in $\mathrm{RHA}$ mortar samples indicating its excellent pozzolanic potential when used as a partial substitute of cement in HPC.

Keywords: pozzolanic, rice husk ash, high performance concrete, thermogravimetric analysis, autogenous shrinkage 


\section{INTRODUCTION}

Since last few decades, concrete has gone through remarkable advancements in terms of achieving high strength, durability, as well as sustainability in construction (Zhang et al., 2003). This could be done by lowering water to cement $(\mathrm{w} / \mathrm{c})$ ratio and adding chemical and mineral admixtures (Aitcin, 2003). Although, lowering $\mathrm{w} / \mathrm{c}$ ratio with adding chemical and mineral admixtures offered high strength, low permeable concretes, it at the same time carried major drawbacks such as self-desiccation and high early-age autogenous shrinkage (Zhengwu et al., 2005; Dejian et al., 2017). Measurement of autogenous shrinkage had been over looked in the past because of clear dominancy of drying shrinkage in conventional concrete mixtures. However, in recent years, the extensive developments of high performance concrete have paved the way to understand more about the phenomena of early-age autogenous shrinkage, especially in very low $\mathrm{w} / \mathrm{c}$ ratio HPCs (Holt, 2001).

TABLE 1 | Physical and chemical analysis of Cherat cement.

\begin{tabular}{|c|c|}
\hline Item & Physical properties \\
\hline $\begin{array}{l}\text { Specific gravity } \\
\left(\mathrm{g} / \mathrm{cm}^{3}\right)\end{array}$ & 3.15 \\
\hline $\begin{array}{l}\text { Blain fineness } \\
\left(\mathrm{m}^{2} / \mathrm{kg}\right)\end{array}$ & 301 \\
\hline $\begin{array}{l}\text { Average particle diameter } \\
(\mu \mathrm{m})\end{array}$ & $\begin{array}{c}<31 \\
\text { (ASTM C 204) }\end{array}$ \\
\hline $\begin{array}{l}\text { Initial setting time } \\
\text { (minutes) }\end{array}$ & $\begin{array}{c}145 \\
\text { (ASTM C 191) }\end{array}$ \\
\hline $\begin{array}{l}\text { Final setting time } \\
\text { (minutes) }\end{array}$ & $\begin{array}{c}230 \\
\text { (ASTM C 191) }\end{array}$ \\
\hline $\begin{array}{l}\text { Consistency } \\
\text { (\%) }\end{array}$ & $\begin{array}{c}28 \\
\text { (ASTM C 187) }\end{array}$ \\
\hline \multirow[t]{2}{*}{$\begin{array}{l}28 \text { days compressive strength } \\
(\mathrm{MPa})\end{array}$} & $\begin{array}{c}45.6 \\
\text { (ASTM C 150) }\end{array}$ \\
\hline & $\begin{array}{c}\text { Chemical properties (oxides, } \\
\% \text { by weight) }\end{array}$ \\
\hline$\overline{\mathrm{SiO}_{2}}$ & 21.24 \\
\hline $\mathrm{Al}_{2} \mathrm{O}_{3}$ & 5.56 \\
\hline $\mathrm{Fe}_{2} \mathrm{O}_{3}$ & 3.24 \\
\hline $\mathrm{CaO}$ & 63.53 \\
\hline $\mathrm{MgO}$ & 0.93 \\
\hline $\mathrm{Na}_{2} \mathrm{O}$ & 0.13 \\
\hline $\mathrm{K}_{2} \mathrm{O}$ & 0.62 \\
\hline $\mathrm{SO}_{3}$ & 2.55 \\
\hline Free Lime & 0.55 \\
\hline $\mathbb{I R}^{*}$ & 0.64 \\
\hline \multirow[t]{2}{*}{ LOI ** } & 1.24 \\
\hline & Compounds (\%) \\
\hline $\mathrm{C}_{3} \mathrm{~S}$ & 47.95 \\
\hline $\mathrm{C}_{2} \mathrm{~S}$ & 24.72 \\
\hline $\mathrm{C}_{3} \mathrm{~A}$ & 8.76 \\
\hline $\mathrm{C}_{4} \mathrm{AF}$ & 9.86 \\
\hline
\end{tabular}

"Insoluble residue, " LOI, loss on ignition.
Autogenous shrinkage in high strength concretes has always remained a great concern. This is because of its susceptibility to shrinkage cracking at early ages due to its very low tensile strength as compared to shrinkage-induced stresses (Holt and Leivo, 2004). Such shrinkage-associated cracking may interconnect with the water flow paths and thus increases the permeability of concrete. This eventually open the chances of water diffusion and chemical attacks from external environment (Wang et al., 1997), which leads to steel corrosion, structural degradation, endangering of load bearing capacity, and durability of concrete facilities (Didier et al., 2015).

Unlike conventional concretes, the normal external curing water cannot easily diffuse in to the interior of HPCs due to their highly dense microstructure. Therefore, the conventional external curing techniques become relatively ineffective to apply in HPCs with very low w/c (Christof et al., 2012). Considering this, different techniques have been adopted in the past to mitigate autogenous shrinkage from HPCs to avoid its associated risk of early-age cracking (Philleo, 1991; Jensen and Hansen, 2001; Jensen and Lura, 2006). Numerous researchers (Bentur et al., 2001; Zhutovsky et al., 2002; Lura et al., 2004; Ghourchian et al., 2013) introduced the concept of using porous lightweight aggregates (LWA) as a medium of internal curing against shrinkage strain and found it very effective. Many others (Ye, 2003; Mechtcherine and Reinhardt, 2012) have used supperabsorbent polymers (SAP) and found it effective as well in controlling autogenous shrinkage. However, the economic factor due to the general un-availability of LWA, and the negative impacts of SAP on pore structure adversely affects other properties of HPCs (Dudziak and Mechtcherine, 2008; Möser et al., 2010). Therefore, some other studies urge using porous supper fine powders such as rice husk ash, cenospheres, boron mud, and bottom ash as they can significantly contribute in reducing autogenous shrinkage of HPCs (Tuan et al., 2010; Wyrzykowski et al., 2016; Liu et al., 2017). These powder materials were found very effective in controlling autogenous shrinkage of HPCs due to their relatively smaller particle size, high specific surface area (SSA), mesoporous structure, and strong water absorbing ability (Huang and Zhang, 2015). Among them, the RHA is currently most commonly used internal curing agent to control shrinkage in HPCs (Tuan et al., 2010; VietThien-An et al., 2014; Jianhui et al., 2017). However, contrary to this, it was found that the fine RHA resulted in increased autogenous shrinkage, even higher than the control concrete (Habeeb and Fayyadh, 2009). Other than the influence of mechanical treatments, its role in controlling shrinkage and other properties of concrete also differs due to its source or country of origin. This is because the composition of RHA changes from region to region and is mainly dependent on crop variety, soil, and fertilizer chemistry and weather condition (Sensale et al., 2008; Okutani, 2009; Onojah et al., 2012). Furthermore, the burning temperature, duration of burning, and the rate of burning have significant effects on the amount of silica content in RHA (Della et al., 2002; Binod et al., 2010; Suryana et al., 2018). Therefore, there is still a need to explore more about the role of RHA in mitigating autogenous shrinkage considering its region of production, burning temperature, 
TABLE 2 | Grain size distribution of coarse and fine aggregates (ASTM C 33).

\begin{tabular}{|c|c|c|c|c|c|}
\hline Sieve \# & Sieve size $(\mathrm{mm})$ & Weight retained $(g)$ & Weight retained $(\%)$ & Cumulative passing (\%) & Cumulative retained (\%) \\
\hline \multicolumn{6}{|c|}{ COARSE AGGREGATE (CA) } \\
\hline 1 inch & 25 & 0 & 0 & 100 & 0 \\
\hline 3/4 inch & 19 & 607 & 30.4 & 69.6 & 30.4 \\
\hline $1 / 2$ inch & 12.5 & 1032 & 51.6 & 18.0 & 82.0 \\
\hline 3/8 inch & 9.5 & 244 & 12.2 & 5.76 & 94.2 \\
\hline No. 4 & 4.75 & 115.2 & 5.76 & 0.0 & 100 \\
\hline \multicolumn{6}{|c|}{ FINE AGGREGATE (FA) } \\
\hline 3/8 inch & 9.5 & 0 & 0 & 100 & 0 \\
\hline No. 4 & 4.75 & 0 & 0 & 100 & 0 \\
\hline No. 8 & 2.36 & 6.5 & 1.3 & 98.7 & 1.3 \\
\hline No. 16 & 1.18 & 35.5 & 7.1 & 91.6 & 8.4 \\
\hline No. 30 & 0.600 & 200.5 & 40.1 & 51.5 & 48.5 \\
\hline No. 50 & 0.300 & 198.5 & 39.7 & 11.8 & 88.2 \\
\hline No. 100 & 0.150 & 58.985 & 11.797 & 0.003 & 99.997 \\
\hline No. 200 & 0.075 & 0.015 & 0.003 & 0 & 0 \\
\hline
\end{tabular}

Fineness Modulus of FA $=(0+0+1.3+8.4+48.5+88.2+99.997) / 100=2.46$

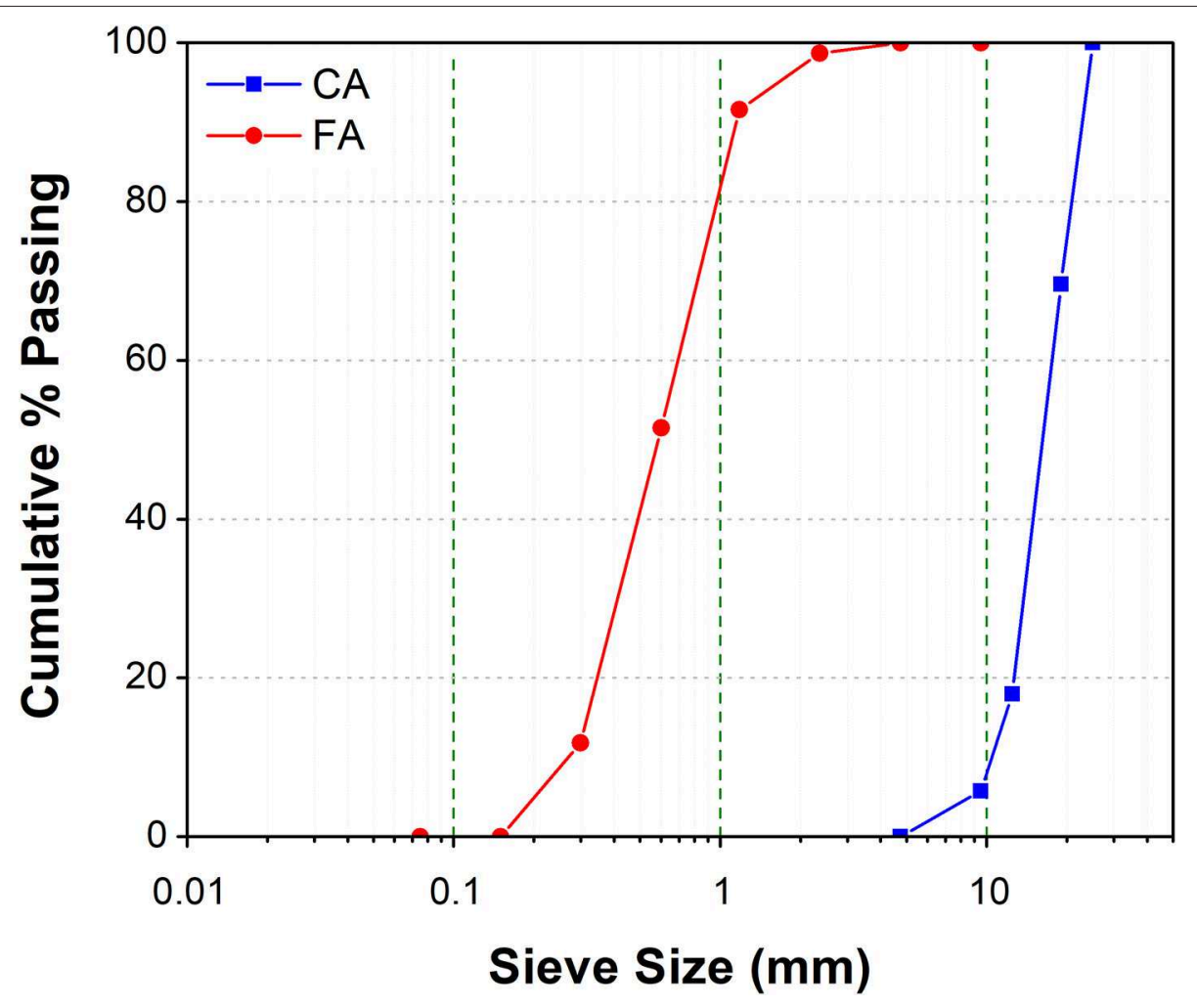

FIGURE 1 | Grain size distribution of coarse and fine aggregates.

fineness and so on, as they directly affect composition of RHA in a significant manner.

Therefore, considering the potential technical benefits, current study was conducted on a locally produced rice husk from Khyber Pukhthunkhwa province of Pakistan to obtain the economic benefits. At first, incinerating of rice husk conducted under different controlled temperatures $\left(700\right.$ and $\left.950^{\circ} \mathrm{C}\right)$ in order to attain its reactive amorphous form. Subsequently, detailed XRD and EDX analyses were performed to study its amorphous siliceous phases. Eventually, the amorphous RHA was grounded to desired fineness in a ball mil and used as a substitute of cement in different percentages $(10,15$, and $20 \%)$ to study 
its effectiveness in mitigating autogenous shrinkage. Concrete cylinders $(150 \times 300 \mathrm{~mm})$ and rectangular beams $(100 \times 100$ $\times 800 \mathrm{~mm}$ ) were cast to measure compressive strength and linear autogenous shrinkage of concrete with and without RHA. The experimental results of compressive strength and shrinkage were compared between control concrete (100\% OPC) and the concrete containing locally produced RHA. At the end, the pozzolanic potential of amorphous RHA was validated through TGA, SEM, and EDX analyses.

\section{MATERIALS AND METHODS}

\section{Materials}

\section{Cement}

A locally available OPC complying ASTM C 150 was obtained from Cherat cement factory to use in this study. Its important physical and chemical properties are listed in Table $\mathbf{1}$.

\section{Aggregates}

Crushed gravel of nominal maximum size $19 \mathrm{~mm}$ and natural sand from river bed were obtained from a local supplier to use them as coarse and fine aggregates, respectively. Before mix design, laboratory tests were performed to determine their detailed physical and chemical properties according to ASTM standard procedures (ASTM C 127, ASTM C 128, ASTM C 136). The bulk density, specific gravity, and moisture absorption of coarse aggregate were $1,557 \mathrm{~kg} / \mathrm{m}^{3}, 2.66$, and $1.86 \%$, respectively. The specific gravity and moisture absorption of sand were 2.50 and $1.49 \%$, respectively. The fineness modulus of sand used in this study was 2.38. A summary of grain size distribution of

TABLE 3 | Technical data of chemrite 520 BA.

\begin{tabular}{ll}
\hline Type & Organic polymer blend \\
\hline Storage condition & Store in dry area between 5 and $35^{\circ} \mathrm{C}$ \\
Density & $1.18 \mathrm{~kg} /$ liter \\
$\mathrm{pH}$ & 7 \\
Dosage & $0.6-3 \%$ by cement weight \\
Chloride content & Nil
\end{tabular}

crushed gravel and sand is given in Table 2. Figure 1 illustrates the grain size distribution of both fine and coarse aggregates.

\section{Chemical Admixture}

To achieve good consolidation, Chemrite-520 was used as a Superplasticizer (SP) to control water to binder ratio $(w / b)$. Several laboratory trials were made to set the dosage of SP for a target slump between 50 and $75 \mathrm{~mm}$. The technical data of Chemrite-520 is given in Table 3.

\section{Rice Husk Ash (RHA)}

Rice husk used in this study was obtained from Malakand division, Khyber Pakhtunkhwa, Pakistan. Figure 2a shows the rice husk in its raw form as obtained. The raw sample of rice husk was incinerated under different controlled temperatures as the amount and the phase of silica (amorphous or crystalline) in RHA greatly dependent on the range and duration of incineration. To achieve silica in amorphous form, the rice husk was burnt under two different temperatures of 700 and $950^{\circ} \mathrm{C}$ in a rotary kiln (Amin et al., 2019). For both temperatures, burning duration was kept same to $3 \mathbf{h}$. Figure $\mathbf{2 b}$ shows the color of RHA after burning at high temperatures $\left(700\right.$ and $\left.950^{\circ} \mathrm{C}\right)$.

Following burning, characterization of RHA using EDX, and $\mathrm{XRD}$ analyses was performed to study the effects of heating

TABLE 4 | Chemical composition of rice husk ash used in this study with respect to burning temperature.

\begin{tabular}{llcc}
\hline Property & Formula & $\begin{array}{l}\text { RHA (\%) } \\
\text { (Burning } \\
\text { temperature } 700^{\circ} \mathbf{C} \text { ) }\end{array}$ & $\begin{array}{l}\text { RHA (\%) } \\
\text { (Burning } \\
\text { temperature 950 }{ }^{\circ} \mathbf{C} \text { ) }\end{array}$ \\
\hline Silica dioxide & $\mathrm{SiO}_{2}$ & 88.02 & 89.20 \\
Aluminum oxide & $\mathrm{Al}_{2} \mathrm{O}_{3}$ & 0.28 & 0.67 \\
Iron oxide & $\mathrm{Fe}_{2} \mathrm{O}_{3}$ & 0.31 & 0.57 \\
Calcium oxide & $\mathrm{CaO}$ & 2.58 & 1.09 \\
Magnesium oxide & $\mathrm{MgO}$ & 0.65 & 0.87 \\
Potassium dioxide & $\mathrm{K}_{2} \mathrm{O}$ & 2.223 & 1.29 \\
Sodium oxide & $\mathrm{Na}_{2} \mathrm{O}$ & - & 0.13 \\
Sulfur trioxide & $\mathrm{SO}_{3}$ & 0.184 & - \\
Loss on ignition & $\mathrm{LOI}$ & 5.75 & 6.18
\end{tabular}
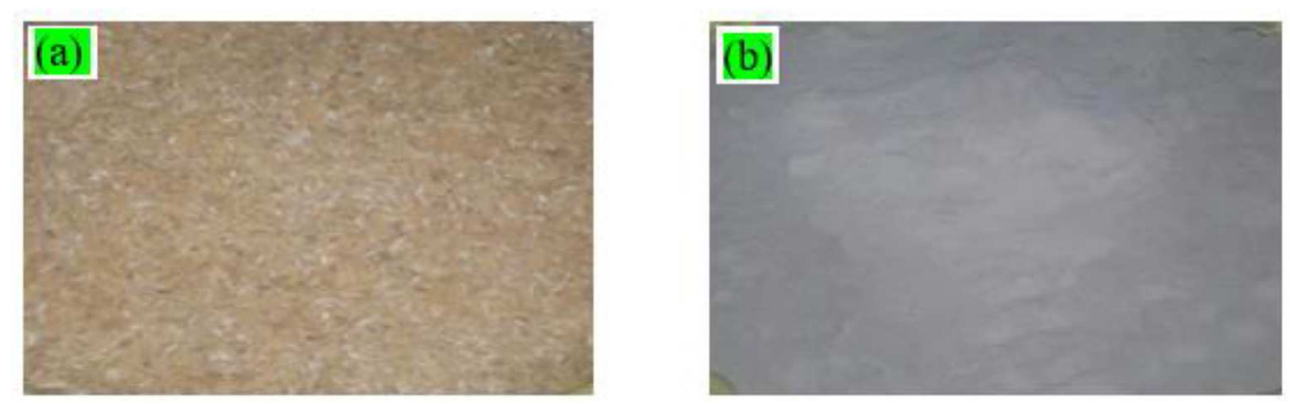

FIGURE 2 | (a) Rice husk in raw form, (b) RHA after burning at high temperatures of 700 and $950^{\circ} \mathrm{C}$. 
temperatures on its chemical composition as well as nature whether amorphous or crystalline.

\section{Energy-Dispersive X-Ray Analysis (EDX)}

The elemental composition of RHA incinerated at different temperatures of 700 and $950^{\circ} \mathrm{C}$ was computed by subjecting RHA sample to EDX in centralized resource laboratory (CRL), Peshawar, Pakistan. The specification of EDX are Model JSM5910, Make INCA200/Oxford instrument, UK, Range Boron to Uranium.

The chemical composition of RHA samples in terms of percent oxide were calculated from the atomic weight yielded by the EDX. The values of chemical composition for both RHA samples treated at 700 and $950^{\circ} \mathrm{C}$ are given in Table 4. It indicated that both RHA samples predominantly composed of silica regardless of their incinerated temperatures. RHA sample burnt at relatively high temperature, such as $950^{\circ} \mathrm{C}$ possess slightly high amount of silica as compared to RHA burnt at $700^{\circ} \mathrm{C}$. According to ASTM C 618, a material containing sum of alumina, silica, and iron more than or equal to $70 \%$ can be
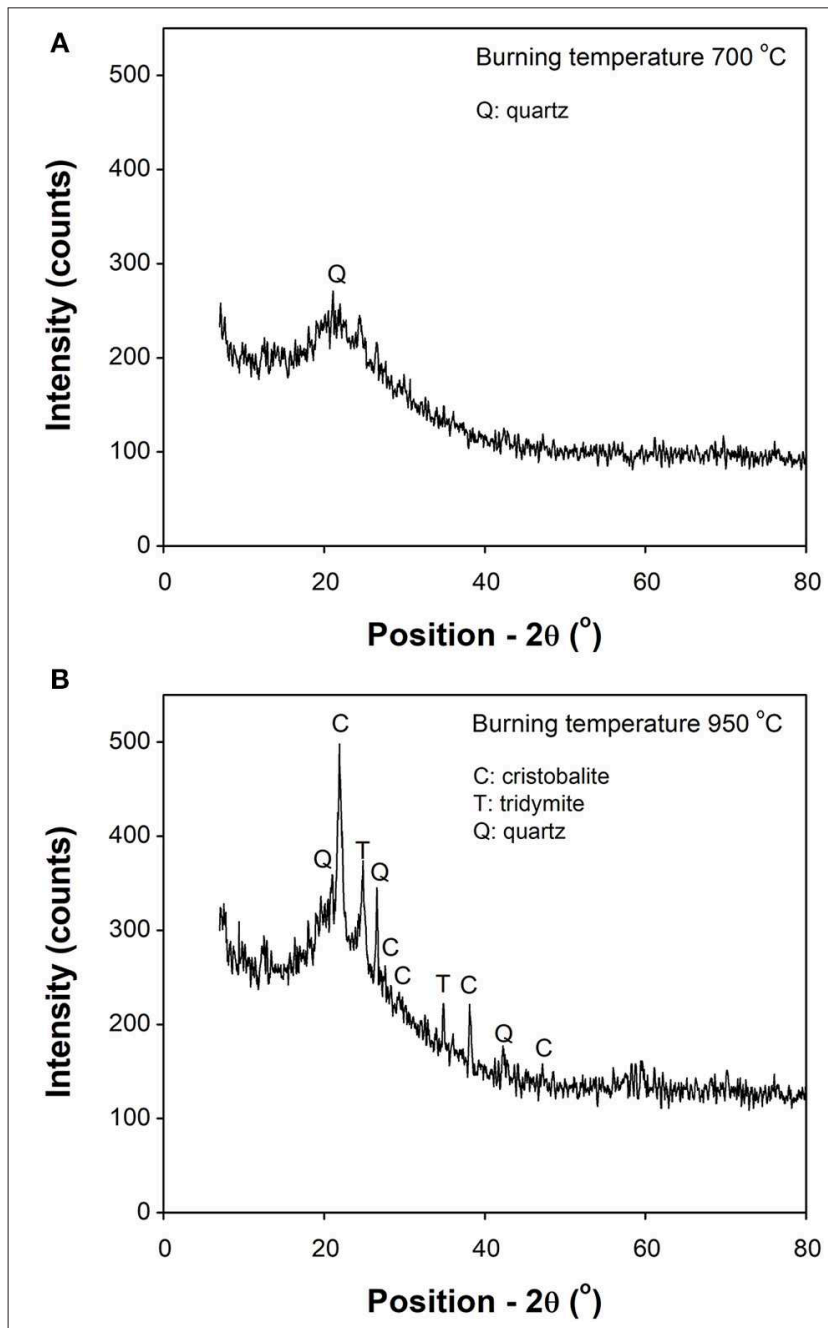

FIGURE 3 |XRD pattern of RHA treated at temperature (A) $700^{\circ} \mathrm{C}$, (B) $950^{\circ} \mathrm{C}$. treated as a potential pozzolanic material. The sum of $\mathrm{SiO}_{2}$, $\mathrm{Al}_{2} \mathrm{O}_{3}$, and $\mathrm{Fe}_{2} \mathrm{O}_{3}$ values given in Table 4 was calculated as 89.61 and $90.44 \%$ for RHA burnt at 700 and $950^{\circ} \mathrm{C}$, respectively. This, according to ASTM criteria, demonstrated RHA as potential pozzolanic material.

\section{X-Ray Diffraction Analysis (XRD)}

Burning rice husk at high temperature may leads to transformation of amorphous form of silica to crystalline form. Formation of cristobalite and tridymite were reported in literature specifically when the rice husk being burnt at temperatures $700^{\circ} \mathrm{C}$ or above (Khalaf et al., 1984; Agrawal, 1989; Waheed et al., 2018). Therefore, in order to identify the different phases formed, XRD analyses were conducted on RHA samples treated at both 700 and $950^{\circ} \mathrm{C}$ temperatures. For this, X-Ray diffractometer [Model- JDX3532, Make - Jeol Japan, X-Ray CuKa $(I=1.5418 \AA)$, 2-theta

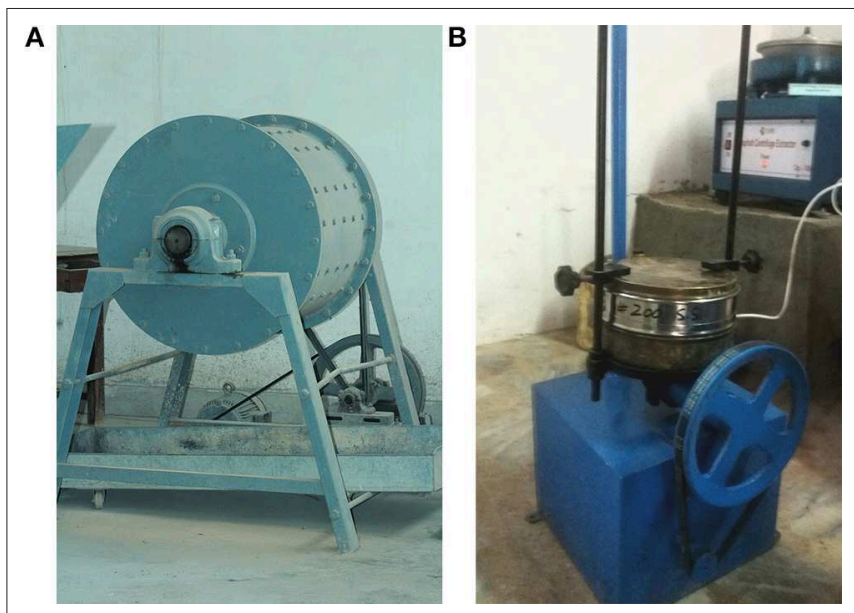

FIGURE 4 | (A) Ball mill used in grinding of RHA, and (B) Sieve shaker used to obtain the $\mathrm{RHA}$ finer that 75 -micron for using in this study.

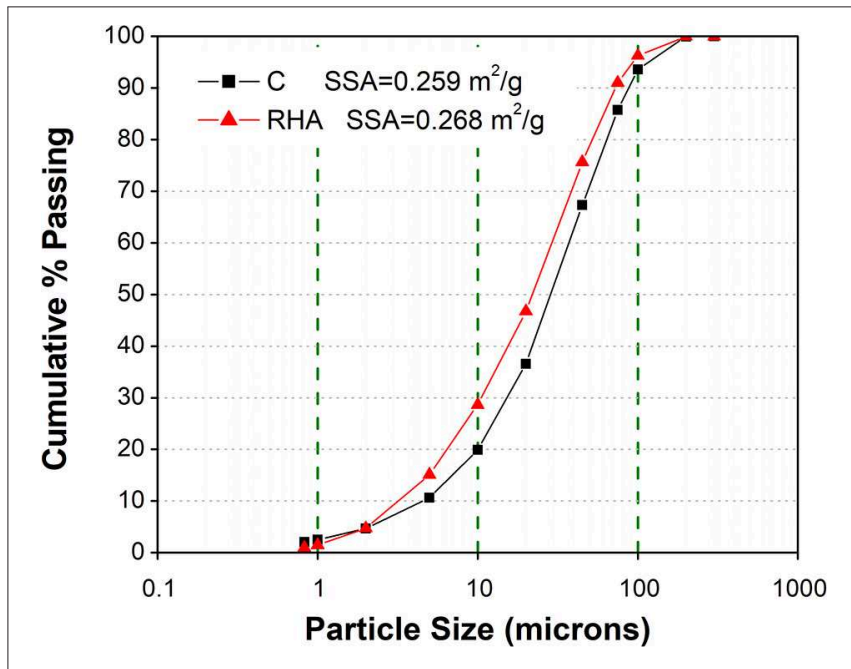

FIGURE 5 | Comparative particle size distribution curves of cement and RHA (passing 75-micron sieve). 
range from 0 to $80^{\circ}$ ] was used and the XRD pattern of RHA samples according to their burning temperatures is shown in Figure 3.

The XRD pattern of RHA burned at $700^{\circ} \mathrm{C}$ (Figure 3A) showed a single diffuse wide band centered at 2-theeta value of $21.6^{\circ} \mathrm{C}$, which indicates the presence of amorphous form of silica. The presence of high amount of amorphous silica will be responsible for pozzolanic reactivity of RHA in mortar and concrete matrix. However, the XRD pattern of RHA incinerated at $950^{\circ} \mathrm{C}$ showed several clearly visible strong peaks of cristobalite at 21.93, 27.63, 28.16, 38.35, and $47.13^{\circ}$ (Figure 3B). Along with strong cristobalite peaks, comparatively weak peaks of tridymite were also noticed at 24.85 and $34.73^{\circ}$. This is because of the crystallization of $\mathrm{SiO}_{2}$ to tridymite-O (Metha and Pitt, 1976; Bie et al., 2015). The presence of strong cristobalite peaks accompanied by weak tridymite revealed the transformation of amorphous silica to crystalline form when burned at high temperature of $950^{\circ} \mathrm{C}$.

\section{Particle Size Analysis of Cement and RHA}

As mentioned earlier in section X-ray Diffraction Analysis (XRD), the focus of this research was to first achieve the amorphous form of silica in RHA, which was successfully done by burning rice husk at $700^{\circ} \mathrm{C}$. Eventually, the RHA obtained from treatment at $700^{\circ} \mathrm{C}$ was placed in a ball mill to grind it for $2 \mathrm{~h}$ followed by sieving through sieve \# 200 (75microns). Figure 4 shows the experimental set up of ball mill and sieve shaker used for grinding and sieving, respectively. After obtaining the desired chemical composition and amorphous nature of RHA, achieving its greater SSA and finer particle size distributions was inevitable for using it as a partial substitute of cement.

After sieving, the particle size analysis of RHA sample passing through sieve \# 200 was carried out. For this, a laser particle size analyzer MicroBrook 2000LD was used. A comparison of particle size distribution between Cherat cement and RHA is shown in Figure 5. The particle size curve of RHA depicting presence of high percentage of all particle sizes as compared to cement, except smaller size particles below 2-micron where it slightly reduced than cement. In addition to the particle size comparison, the specific surface area (SSA) of both binder materials (cement and RHA) was also calculated using same MicroBrook 2000LD laser particle size analyzer. As expected looking at particle size curves, ii turned out $0.268 \mathrm{~m}^{2} / \mathrm{g}$ for RHA as slightly greater than that of cement $\left(0.259 \mathrm{~m}^{2} / \mathrm{g}\right)$. For sake of quick comparison between

TABLE 5 | Comparison of $d_{10}, d_{50}$, and dgo values of Cement and RHA.

\begin{tabular}{llll}
\hline Materials & $\begin{array}{l}\mathrm{d}_{\mathbf{1 0}} \\
(\boldsymbol{\mu \mathrm { m } )}\end{array}$ & $\begin{array}{c}\mathrm{d}_{\mathbf{5 0}} \\
(\boldsymbol{\mu \mathrm { m } )}\end{array}$ & $\begin{array}{c}\mathrm{d}_{\mathbf{9 0}} \\
(\boldsymbol{\mu \mathrm { m } )}\end{array}$ \\
\hline Cement & 4.682 & 29.15 & 86.56 \\
RHA & 3.469 & 22.17 & 71.75
\end{tabular}

cement and RHA, the values of their $\mathrm{d}_{10}, \mathrm{~d}_{50}$, and $\mathrm{d}_{90}$ sizes are presented in Table 5.

\section{Mix Proportions and Test Methods Mix Proportions}

Concrete mix proportion used in this study was designed following the ACI mix design method ACI 211.1. The target slump and average 28 days compressive strength of control concrete were set as 50 to $75 \mathrm{~mm}$ and $43 \mathrm{MPa}$, respectively. After several laboratory trials, mix proportions for this study were finalized as listed in Table 6 . The w/b ratio as shown in Table 6 was kept same for all mixes and the amount of water added during mixing $\left(188 \mathrm{~kg} / \mathrm{m}^{3}\right)$ was used for only hydration reaction and concrete workability. The aggregates (fine and coarse) were added in saturated surface dry state in the mixing to achieve same effective $\mathrm{w} / \mathrm{b}$ ratio of 0.33 for all mixes.

In trial mixes, the workability of concrete mixes containing RHA drastically reduced due to the high SSA of RHA (Ganesan et al., 2008). Moreover, the water demand increased further with increasing percentage of RHA, which eventually compensated by adding SP. Accordingly, the different dozes of SP were set for each mix proportion (Table 6) to maintain a desired target slump between 50 and $75 \mathrm{~mm}$.

To investigate the effectiveness of RHA in reducing autogenous shrinkage, the mass of cement in the control mix (C-Mix) was substituted with RHA by 10,15 , and $20 \%$. The mixes with RHA were identified as R-10, R-15, and R-20 for concrete containing 10,15 , and $20 \%$ RHA, respectively.

\section{Specimen Preparation and Test Methods}

Immediately after mixing, three identical concrete cylinders (150 mm dia $\times 300 \mathrm{~mm}$ height) were cast for each mix (Table 6) in accordance with ASTM C 39 to measure the compressive strength of concrete. After casting, specimens were covered from top to prevent moisture loss and demolded after $24 \mathrm{~h}$ followed by moist curing. The test was performed by using a universal testing

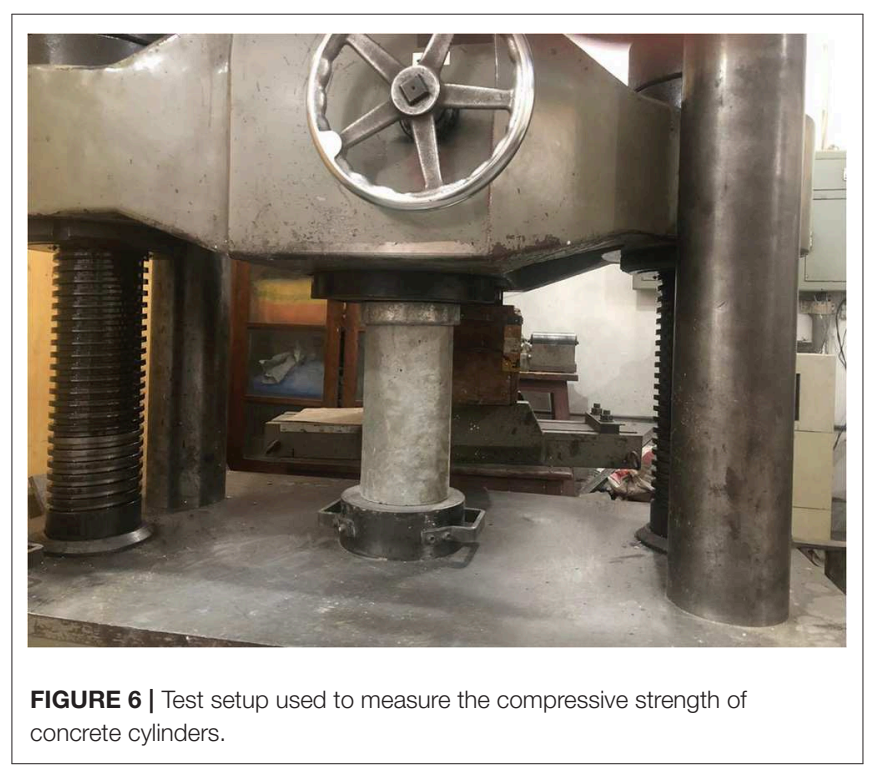


TABLE 6 | Mix proportion of control concrete and concretes containing different percentages of RHA.

\begin{tabular}{|c|c|c|c|c|c|c|c|c|}
\hline \multirow[t]{2}{*}{ Mix ID } & \multirow[t]{2}{*}{$w / b$} & \multirow{2}{*}{$\begin{array}{c}\text { Cement } \\
\text { replacement with RHA (\%) }\end{array}$} & \multicolumn{5}{|c|}{ Unit weight $\left(\mathrm{kg} / \mathrm{m}^{3}\right)$} & \multirow{2}{*}{$\begin{array}{l}\mathrm{SP}^{\star} \\
(\%)\end{array}$} \\
\hline & & & $\mathbf{w}$ & C & RHA & FA & CA & \\
\hline Control Mix (C-Mix) & 0.33 & 0 & 188 & 570 & 0 & 627 & 1,117 & 0.90 \\
\hline $10 \% \mathrm{RHA}(\mathrm{R}-10)$ & 0.33 & 10 & 188 & 513 & 57 & 538 & 1,078 & 1.13 \\
\hline 15\% RHA (R-15) & 0.33 & 15 & 188 & 485 & 85 & 538 & 1,078 & 1.20 \\
\hline 20\% RHA (R-20) & 0.33 & 20 & 188 & 456 & 114 & 538 & 1,078 & 1.25 \\
\hline
\end{tabular}

*\% by weight of binder.
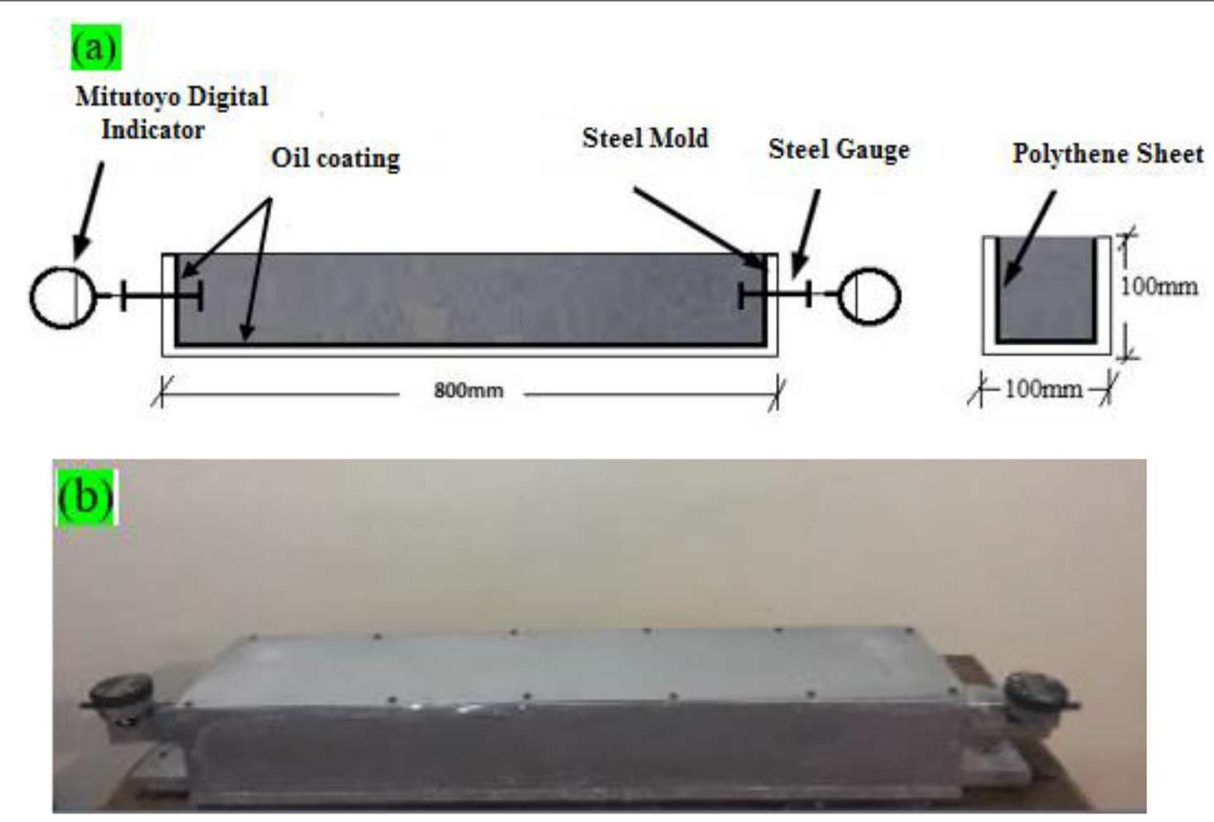

FIGURE 7 | (a) Schematic to measure autogenous shrinkage in concrete, (b) Experimental set up to measure linear autogenous shrinkage in concrete with and without RHA.

machine shown in Figure 6. For each mix proportion, average value of three identical specimens was calculated.

In parallel to compressive tests, the linear autogenous shrinkage of concrete mixes was measured by using Mitutoyo IDC-112 digital indicators (Salman et al., 2014). Figure 7 shows the schematic and the experimental set up used to measure the linear autogenous shrinkage.

For each mix proportion, three identical prismatic concrete beams of size $100 \times 100 \times 800 \mathrm{~mm}$ were cast to calculate their average value. Immediately after casting, the specimens were covered from top by steel plate screwed into side plates of mold (Figure 7). This was done to prevent any moisture transport between environment and surfaces of specimen to ensure measurement of pure autogenous shrinkage. By doing this, occurrence of early-age plastic and drying shrinkages were completely prevented. The first reading of shrinkage was taken upon reaching of final setting time, about $6 \mathrm{~h}$ after casting. After this, the readings of autogenous shrinkage were taken every $6 \mathrm{~h}$ until the age of 7 days. The measurement was terminated at age of 7 days as no significant changes in reading of autogenous shrinkage was observed afterwards. Finally, the average shrinkage results of concrete containing different percentages of RHA (10, 15 , and $20 \%$ ) were compared with those of control concrete without RHA.

\section{RESULTS AND DISCUSSIONS}

\section{Compressive Strength of Concrete With and Without RHA}

Influence of locally produced RHA on strength HPC was critically analyzed in this study. The target 28 days strength of continuously moist cured cylinders of C-Mix was measured as $43 \mathrm{MPa}$. According to the current results, the compressive strength after different percentage substitutions of cement with RHA (R-10, R-15, R-20) remained almost same to that of control concrete. Figure 8A shows the histogram of compressive strength for all mixes for their three identical specimens, and Figure 8B shows the comparison of their average 28 days compressive strengths with error bars as a standard deviation of three identical 
specimens. Only a slight increase in average strength than the control concrete was noticed in concrete having 10\% RHA (44.2 $\mathrm{MPa}$ ), which is in good agreement with previous studies on cement, mortar, and concrete (James and Rao, 1986; Malhotra and Mehta, 1996; Zhang and Malhotra, 1996; Zhang et al., 1996; Rodriguez de Sensale, 2006; Giaccio et al., 2007; Sensale et al., 2008; Ramasamy, 2011). However, contrary to $10 \%$ RHA concrete, a small reduction in strength was observed in concretes with 15 and 20\% RHA (42.8 and $41.8 \mathrm{MPa}$, respectively). This trend of decrease in strength with increasing percentage of RHA also reported by Ramasamy (2011), except that he found greater strength reduction as compared to trends of current study. According to Ramasamy (2011), compressive strength decreased with increasing percentage of RHA more than $10 \%$, and it reduced further with addition of SP in the concrete. This is because the amount of saturated water absorption increased in the concrete containing RHA up to $10 \%$, which eventually diminished with addition of SP.

Unlike past studies, the current results demonstrated clearly the benefits of using even higher percentages of locally produced

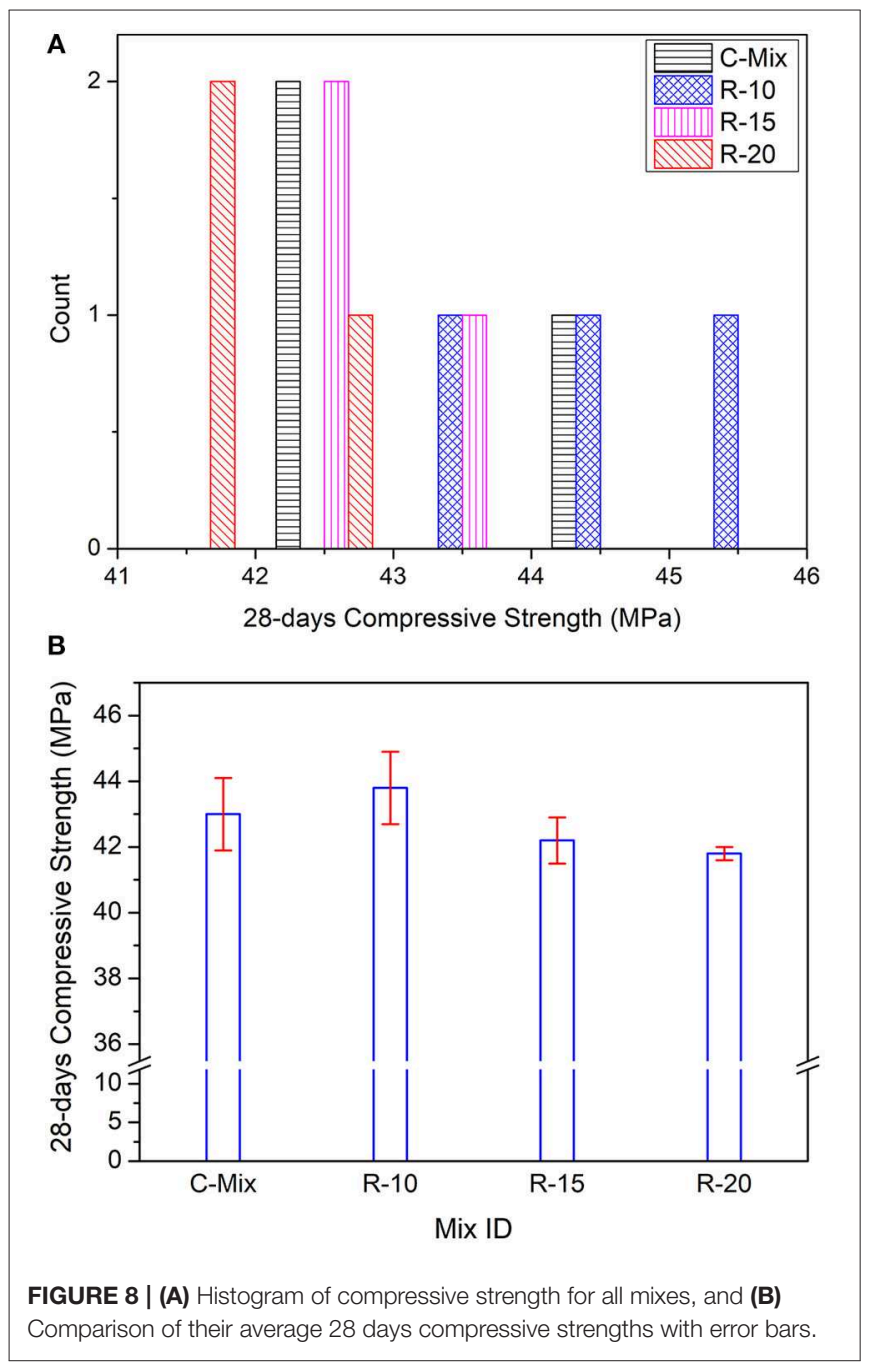

RHA (up to 20\%) in concrete without compromising the compressive strength of concrete. The slight increase (R-10) or close compressive strength of RHA concretes (R-15 and R-20) to control concrete can be attributed to simultaneous micro-filler effects and better pozzolanic reactivity of local RHA. Researchers in the past have systematically investigated the role of RHA in uniform distribution of hydration products in available space, thus, resulting in denser matrix and better mechanical strength (Zhang and Malhotra, 1996; Rama Rao and Seshagiri Rao, 2003).

\section{Influence of RHA on Autogenous Shrinkage}

Figure 9 shows the comparison of early-age autogenous shrinkage of concrete containing different percentages of RHA with that of control concrete. As shown in Figure 9, the different concrete mixes used in this study are identified as
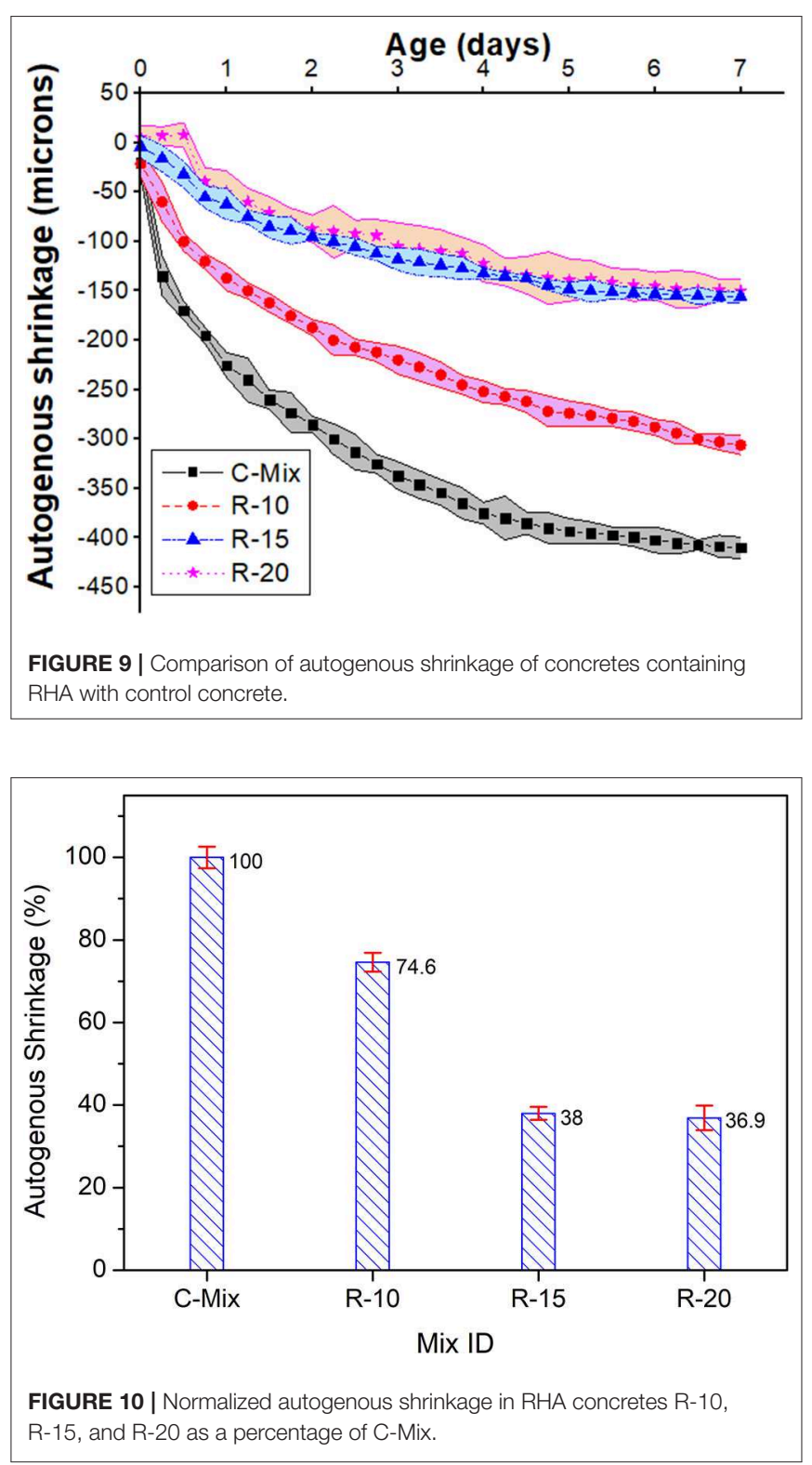
C-Mix, R-10, R-15, and R-20 for control concrete without RHA, concrete containing 10\% RHA, concrete containing 15\% RHA, and concrete containing 20\% RHA, respectively. In general, the variation of hydration temperature in thin sized samples remains very small and uniform among different samples (Amin et al., 2010; Viet-Thien-An et al., 2014). Therefore, the effect of thermal dilation on values of autogenous shrinkage was ignored.

As expected, a significant amount of autogenous shrinkage was generated in C-Mix due to low w/c ratio, which however, decreased significantly with increasing amount of cement substitution with RHA. It can be seen that the maximum autogenous shrinkage occurred in C-Mix was $410 \mu \mathrm{m}$ at age of 7 days and reduced to 306,156 , and $150 \mu \mathrm{m}$ in R-10, R-15, and R-20, respectively. For each mix, the scatter of shrinkage data of three identical specimens was described by highlighting the area of variability from the mean curves. Figure 9 shows that the rate of development of autogenous shrinkage dropped remarkably right from the beginning in concrete containing RHA. Moreover, the rate of drop of autogenous shrinkage increased with increasing percentage of RHA. It was particularly noticeable in concrete containing 15 to $20 \%$ RHA. The current results of decreased autogenous shrinkage in concrete containing RHA are consistent with the finding of previous studies (Nguyen, 2011) and, therefore, suggesting reliable use of RHA in mitigating autogenous shrinkage of high strength concrete. A slight expansion in R-20 during first $12 \mathrm{~h}$ measured from zero time is due to the prolonged induction period caused by the strong retarding effect of relatively high dosage of SP (Ramasamy, 2011). Moreover, it is obvious that the reduced amount of cement in R-20 mix lead to lesser cement hydration and, thus, low shrinkage at early ages.

The reduction of autogenous shrinkage at early ages is attributed to the fact that the RHA absorb water due to its mesoporous cellular structure and high fineness, and eventually act as an internal curing agent in matrix. The absorption of water by RHA in aqueous phase decreased free water initially in the matrix and, thereafter, releases continuously to the system for hydration and thus control the internal relative humidity. It was confirmed in the past studies that the rate of decrease of internal relative humidity in RHA matrices was lowest as compared to control and other matrices without RHA (Sensale et al., 2008; Viet-Thien-An et al., 2014).

The normalized results of autogenous shrinkage at the age of 7 days in R-10, R-15, and R-20 concrete mixes as a percentage of C-Mix are shown in Figure 10. The standard deviation (SD)

TABLE 7 | Mix proportion of cement sand mortars.

\begin{tabular}{lccccc}
\hline Mix ID & w/b & $\begin{array}{c}\text { Cement } \\
\text { replacement with RHA } \\
\text { (\%) }\end{array}$ & & \multicolumn{2}{c}{ Batch quantities (grams) } \\
\cline { 3 - 6 } & & & C & RHA & FA \\
\hline $\begin{array}{l}\text { Control } \\
\text { mortar (CM) }\end{array}$ & 0.5 & 0 & 500 & 0 & 1,500 \\
$\begin{array}{l}\text { RHA mortar } \\
\text { (RM) }\end{array}$ & 0.5 & 15 & 425 & 75 & 1,500
\end{tabular}

of shrinkage at 7 days for three identical specimens was also shown in Figure 10 through error bars. From Figure 10, it can be clearly seen that the concrete mixes containing RHA as 10,15 , and $20 \%$ produced only $74.6,38.0$, and $36.9 \%$ of autogenous shrinkage to that of C-Mix. Although, decrease of autogenous shrinkage increase with increasing amount of RHA up to $20 \%$. However, decrease of autogenous shrinkage with increasing percentage of RHA was not systematically linear. For instance, autogenous shrinkage reduced significantly with increasing RHA from 10 to $15 \%$, while, it only slightly reduced when increased RHA from 15 to $20 \%$. Based on the above as well as the results of preceding section, it may be safe to conclude that the RHA in concrete up to $20 \%$ produced best results in terms of both strength development and mitigation of autogenous shrinkage.

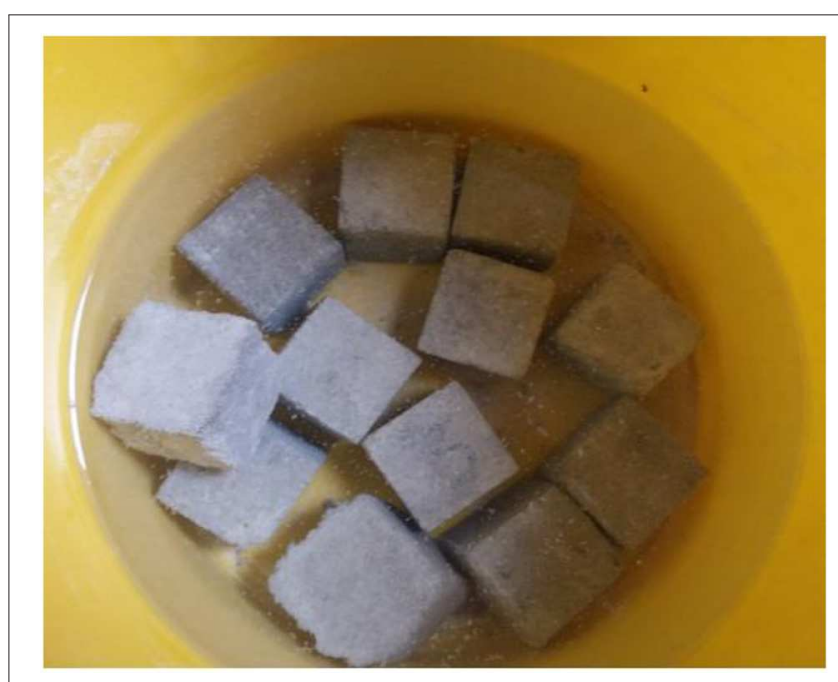

FIGURE 11 | Moist curing of mortar samples for TGA under controlled laboratory conditions.

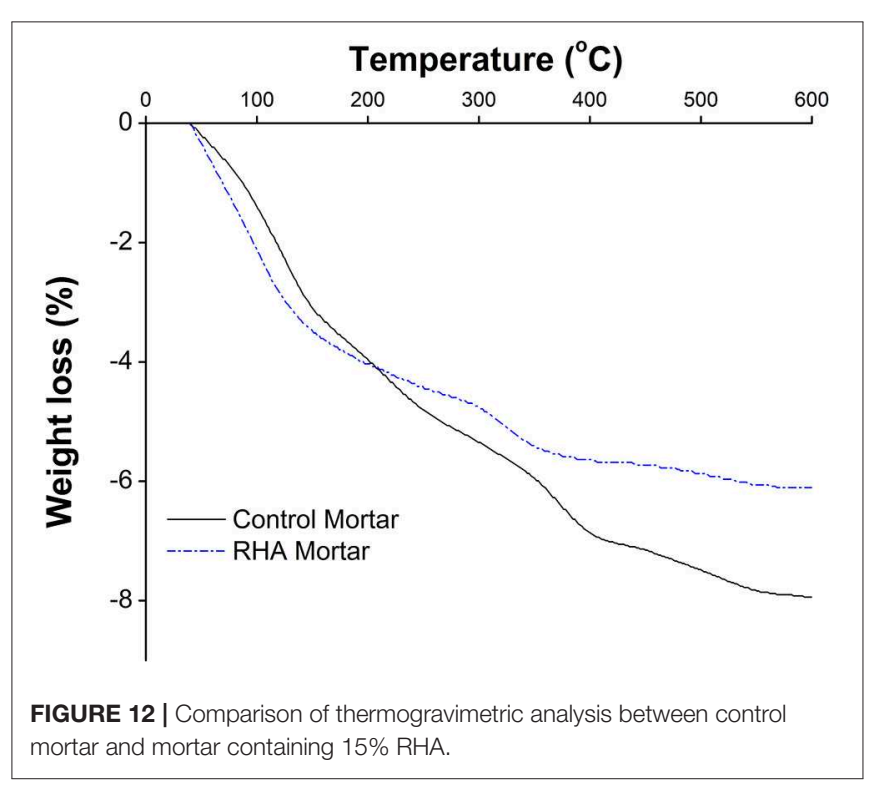




\section{Thermogravimetric Analysis of Mortars With and Without RHA}

Following the initial testing results such as slump, compression strength, and autogenous shrinkage, additional control cement sand mortar and mortar incorporated 15\% RHA were prepared to perform thermal as well as microstructural analysis. This was required to ensure the pozzolanicity of current RHA used in this study. Table 7 shows the details of mix proportion of cement sand mortars used in this study.

As listed in Table 7, samples of cement sand mortar containing $15 \%$ RHA were prepared to perform thermogravimetric analysis and compare its results with control mortar. For TGA, mortar containing only 15\% RHA were cast. This is because replacement of cement with $10 \%$ RHA has not reduced shrinkage significantly as compared to $15 \%$ RHA and also the compressive strength of concrete slightly reduced with increasing percentage of RHA from 15 to $20 \%$ (see section Compressive Strength of Concrete With and Without RHA) without further reduction of shrinkage. After casting, the top surface of mortar molds were sealed with waterproof polyethylene sheet to prevent potential drying. Subsequently, the mortar molds were stored at a safe place in laboratory under controlled environmental conditions of temperature and humidity. All the mortar molds were demolded at age of $24 \mathrm{~h}$ and immersed in water for curing until the age of testing (Figure 11).
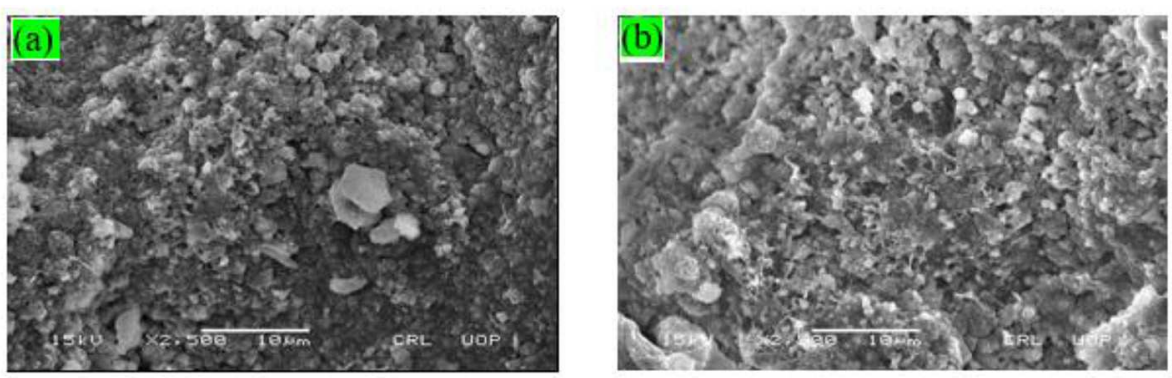

FIGURE 13 | Comparison of SEM between (a) Control mortar, and (b) Mortar containing RHA.

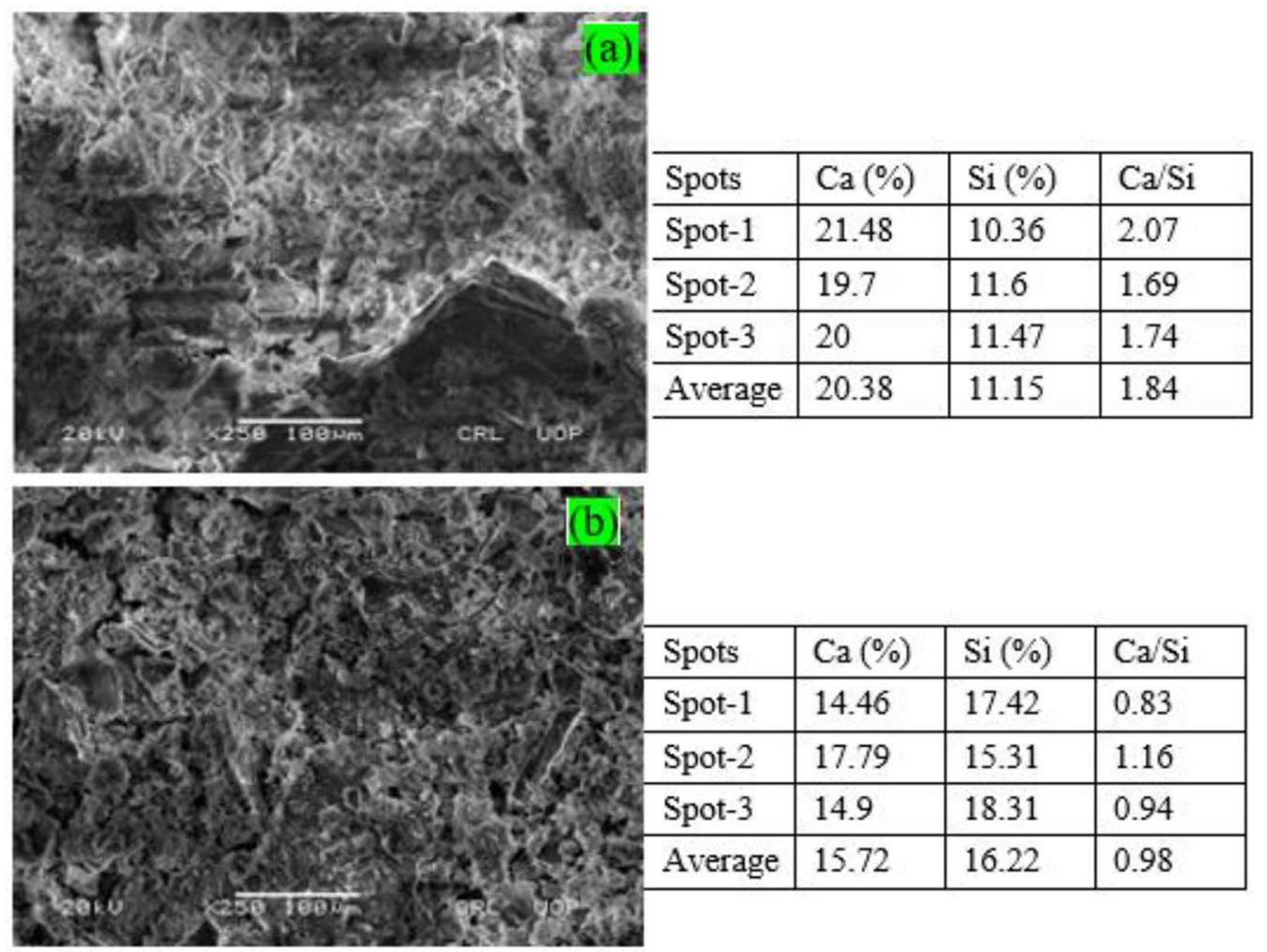

FIGURE 14 | Ca/Si ratio at 91 days in (a) Control mortar, and (b) Mortar containing RHA. 

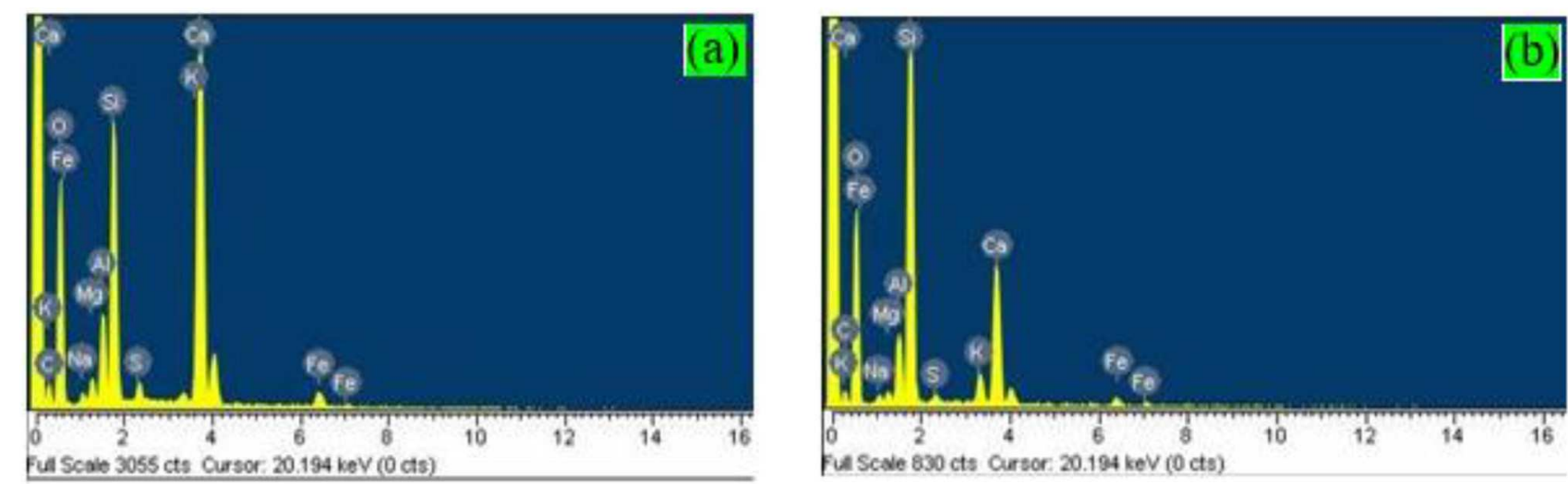

FIGURE 15 | Comparison of EDX spectrum between (a) Control mortar, and (b) Mortar containing RHA.

At age of 91 days, the samples were removed from water and wiped off to perform the TGA. The samples were heated at a rate of $10^{\circ} \mathrm{C} / \mathrm{min}$ starting from $40^{\circ} \mathrm{C}$ and reaching to $600^{\circ} \mathrm{C}$. Figure 12 shows the comparison of TGA results of 15\% RHA mortar with those of control mortar.

Two distinct phases were recognized from this comparison; (i) initial weight loss attributed to dehydration of adsorbed water, capillary pore water, and interlayer water during initial $150^{\circ} \mathrm{C}$, and (ii) weight loss due to decomposition of calcium hydroxide at heating temperature between 300 and $500^{\circ} \mathrm{C}$. From Figure 12, it was evident that more weight loss occurred in RHA mortar than control mortar during first phase $\left(40-150^{\circ} \mathrm{C}\right)$. This could be due to low moisture holding ability of RHA linked to its mesoporous structure. However, less weight loss observed in RHA mortar during second phase $\left(300-600^{\circ} \mathrm{C}\right)$ indicating presence of low calcium hydroxide in RHA mortar as compared to control mortar. This less weight loss in RHA mortar, which is almost $54 \%$ less than control mortar, occurred due to the consumption of calcium hydroxide by pozzolanic reaction of RHA.

\section{Morphological Investigation of Mortars With and Without RHA Using SEM}

The SEM was used to illustrate the pozzolanic reaction of RHA. Similar to TGA, samples of cement sand mortar with and without RHA were prepared for this investigation. Figure 13 shows the SEM images of control as well as RHA mortar. Comparison of images (Figures 13a,b) showed higher quantity of hexagonal calcium hydroxide crystals in control mortar than RHA mortar. This clearly indicated consumption of calcium hydroxide due to pozzolanic reaction of RHA.

Moreover, the chemical composition of hydration product in control and RHA mortars was further investigated by EDX. Specimens continuously moist cured for 91 days were used for both control and RHA mortars. Three different spots were located in microstructure of each mortar specimen to quantify $\mathrm{Ca} / \mathrm{Si}$ ratio of C-S-H (Figure 14).

The EDX results of both control and RHA mortar specimens were also presented in Figure 15. It is evident from EDX spectrum that RHA imparts more siliceous compound to mix after the pozzolanic reaction. It was also observed that $\mathrm{Ca} / \mathrm{Si}$ ratio in RHA mortar is much lower than that of control mortar. This indicated consumption of calcium hydroxide in RHA mortar due to its pozzolanic reaction and that the C-S$\mathrm{H}$ gel formed with lower $\mathrm{Ca} / \mathrm{Si}$ ratio than the control mortar specimen did.

\section{CONCLUSIONS}

This study investigated the pozzolanic potential of locally produced RHA and its potential use in mitigating autogenous shrinkage of HPC. At first, amorphous form of RHA was achieved by burning it to $700^{\circ} \mathrm{C}$, followed by grinding to achieve the desired fineness. Subsequently, the mixture proportions for control and HPC containing RHA (10, 15, and 20\% substitution of cement) were designed for a target slump between 50 and $75 \mathrm{~mm}$, and compressive strength as $43 \mathrm{MPa}$. Eventually, the pozzolanic potential and the influence of RHA in mitigating early-age autogenous shrinkage was assessed. Based on the results, the following are the main conclusions drawn from this study:

- The pattern of XRD results revealed that the burning of rice husk at controlled temperature up to $700^{\circ} \mathrm{C}$ was very effective, as it has yielded silica in amorphous form. Contrary to this, burning rice husk at high temperatures, such as $950^{\circ} \mathrm{C}$, transformed the amorphous silica in to crystalline phase, as noticed from the high intensity peaks of cristobalite and tridymite in XRD pattern.

- The HPC containing different percentages of RHA possess comparable 28 days compressive strength to that of control concrete. However, the workability of concrete reduced with increasing percentage of RHA due to its high SSA. Therefore, increased dosages of SP were added in HPC with increasing percentage of RHA to achieve desired workability such that it is comparable to control concrete.

- Results demonstrated strong influence of locally produced RHA in mitigating early-age shrinkage. Results indicated a 
continuous decrease of autogenous shrinkage with increasing amount of RHA up to $20 \%$. However, decrease of autogenous shrinkage with increasing percentage of RHA was not systematically linear. For instance, autogenous shrinkage reduced significantly with increasing RHA from 10 to $15 \%$, while, it only slightly reduced when increased RHA from 15 to $20 \%$.

- According to SEM and TGA results, the $\mathrm{Ca}(\mathrm{OH})_{2}$ content decreased in mortar containing RHA. This is an indication of excellent pozzolanic potential of RHA when used in concrete as a partial substitute of cement. Furthermore, it also supported by the EDX results, according to which, the addition of RHA imparts relatively higher amount of siliceous compounds to RHA mortar as compared to control mortar after pozzolanic reaction.

- After achieving a comparable compressive strength to that of control concrete and strong influence on mitigating highly problematic early-age autogenous shrinkage, locally produced RHA can be recommended as an advantaged material in terms of its technical as well as economic benefit.

Since many researchers in the past highlighted about the effect of local climatic and soil condition on chemical composition of RHA. Therefore, authors feel that there is still a need to extend this research on RHA produced in different parts of the country, where there is a variation in the climatic and soil conditions. Moreover, the current research also needs to be extended to evaluate the role of particle size of RHA in reducing autogenous shrinkage. Ultra-fine RHA can be more effective in mitigating autogenous shrinkage in ultra-high strength or high performance concretes, where there is a possibility of more autogenous shrinkage due the high amounts of cement used in producing these special types of concrete.

\section{REFERENCES}

Agrawal, B. M. (1989). Utilization of rice husk ash, Glass Ceram. Bull. 36, 1-2.

Aitcin, P. C. (2003). The durability characteristics of high performance concrete: a review. Cem. Concr. Compos. 25, 409-420. doi: 10.1016/S0958-9465(02)00081-1

Amin, M. N., Kim, J. S., Dat, T. T., and Kim, J. K. (2010). Improving test methods to measure early age autogenous shrinkage in concrete based on air cooling. IES J. Part A: Civ. Struct. Eng. 3, 244-256. doi: 10.1080/19373260.2010.522314

Amin, M. N., Murtaza, T., Shahzada, K., Khan, K., and Adil, M. (2019). Pozzolanic potential and mechanical performance of wheat straw ash incorporated sustainable concrete. Sustainability 11:519. doi: 10.3390/su11020519

Bentur, A., Igarashi, S., and Kovler, K. (2001). Prevention of autogenous shrinkage in high strength concrete by internal curing using wet lightweight aggregates. Cem Concr. Res. 31, 1587-1591. doi: 10.1016/S0008-8846(01)0 0608-1

Bie, R.-S., Song, X.-F., Liu, Q.-Q., Ji, X.-Y., and Chen, P. (2015). Studies on effects of burning conditions and rice husk ash (RHA) blending amount on the mechanical behavior of cement. Cem. Concr. Compos. 55, 162-168. doi: 10.1016/j.cemconcomp.2014.09.008

Binod, P., Sindhu, R., and Singhania, R. R. (2010). Bioethanol production from rice straw: an overview. Bioresou. Technol. 10, 4767-4774. doi: 10.1016/j.biortech.2009.10.079

Christof, S., Mechtcherine, V., and Gorges, M. (2012). Relation between the molecular structure and the efficiency of superabsorbent polymers (SAP) as

\section{DATA AVAILABILITY}

No datasets were generated or analyzed for this study.

\section{AUTHOR CONTRIBUTIONS}

$\mathrm{MA}, \mathrm{SH}, \mathrm{KS}$, and KK contributed to the design of this research. $\mathrm{SH}$ and $\mathrm{TB}$ helped in performing the experiments started from collecting rice husk and other concrete ingredients, burning and grinding rice husk, sieving RHA, mixing, casting, demolding, and curing of tested specimens. SH and KS conducted XRD and EDX analyses, and contributed in doing mechanical testing. MA, $\mathrm{SH}$, and $\mathrm{KK}$ contributed in writing the Introduction and the Materials and Method section of manuscript and helped critically analyzed and discussed the current results. MA, SH, KS, and KK contributed in writing and finalized the manuscript.

\section{FUNDING}

This research was supported by the Deanship of Scientific Research (DSR) at King Faisal University (KFU) through Nasher grant \# 186089. The authors wish to express their gratitude for the financial support that has made this study possible. The funds for OAP were also covered by DSR through Nasher grant \# 186089.

\section{ACKNOWLEDGMENTS}

The authors also extend their deep appreciation to Department of Civil Engineering at King Faisal University, Saudia Arabia and Department of Civil Engineering at UET Peshawar, Pakistan for providing lab facilities to conduct the desired experimental tasks.

concrete admixture to mitigate autogenous shrinkage. Cem. Concr. Res. 42, 865-873. doi: 10.1016/j.cemconres.2012.03.011

Dejian, S., Jinliang, J., Wenting, W., Jiaxin, S. H., and Guoqing, J. (2017). Tensile creep and cracking resistance of concrete with different waterto-cement ratios at early age. Constr. Build. Mater. 146, 410-418. doi: 10.1016/j.conbuildmat.2017.04.056

Della, V. P., Kühn, I., and Hotza, D. (2002). Rice husk ash as an alternate source for active silica production. Mater. Lett. 57, 818-821. doi: 10.1016/S0167-577X(02)00879-0

Didier, S., Jensen, O. M., and Belie, N. D. (2015). The influence of superabsorbent polymers on the autogenous shrinkage properties of cement pastes with supplementary cementitious materials. Cem. Concr. Res. 74, 59-67. doi: 10.1016/j.cemconres.2015.03.020

Dudziak, L., and Mechtcherine, V. (2008). "Mitigation of volume changes of ultrahigh performance concrete (UHPC) by using super absorbent polymers," in Proceedings of the 2nd International Symposium on Ultra High Performance Concrete. (Kassel, Germany), 425-432.

Ganesan, K., Rajagopal, K., and Thangavel, K. (2008). Rice husk ash blended cement: assessment of optimal level of replacement for strength and permeability properties of concrete. Constr. Build. Mater. 22, 1675-1683. doi: 10.1016/j.conbuildmat.2007.06.011

Ghourchian, S., Wyrzykowski, M., Lura, P., Shekarchi, M., and Ahmadi, B. (2013). An investigation on the use of zeolite aggregates for internal curing of concrete. Constr. Build. Mater. 40, 135-144. doi: 10.1016/j.conbuildmat.2012. 10.009 
Giaccio, G., Rodríguez de Sensale, G., and Zerbino, R. (2007). Failure mechanism of normal and high-strength concrete with rice-husk ash. Cem. Conc. Comp. 29, 566-574. doi: 10.1016/j.cemconcomp.2007.04.005

Habeeb, G. A., and Fayyadh, M. M. (2009). Rice husk ash concrete: the effect of RHA average particle size on mechanical properties and drying shrinkage. Aust. J. Basic. Appl. Sci. 3, 1616-1622. Available online at: http://www.ajbasweb.com/ old/ajbas/2009/1616-1622.pdf

Holt, E., and Leivo, M. (2004). Cracking risks associated with early age shrinkage. Cem. Concr. Compos. 26, 521-530. doi: 10.1016/S0958-9465(03)00068-4

Holt, E. E. (2001). Early age autogenous shrinkage of concrete, Technical Research Centre of Finland, Espoo, Finland 446:2001. Available online at: https://www. vtt.fi/inf/pdf/publications/2001/P446.pdf

Huang, Z. Y., and Zhang, C. B. (2015). Effect of porous superfine powder on the performance of ultra high performance concrete. Bull. Chin. Ceram. Soc. doi: 10.4324/9781315705835

James, J., and Rao, M. S. (1986). Reactivity of rice husk ash. Cem. Conc. Res. 16, 296-302. doi: 10.1016/0008-8846(86)90104-3

Jensen, O. M., and Hansen, P. F. (2001). Water-entrained cement-based materials: I. Principles and theoretical background. Cem. Concr. Res. 31, 647-654. doi: 10.1016/S0008-8846(01)00463-X

Jensen, O. M., and Lura, P. (2006). Techniques and materials for internal water curing of concrete. Mater. Struct. 39, 817-825. doi: 10.1617/s11527-006-9136-6

Jianhui, L., Caijun, S., Xianwei, M., Kamal, H. K., Jian, Z., and Dehui, W. (2017). An overview on the effect of internal curing on shrinkage of high performance cement-based materials. Constr. Build. Mater. 146, 702-712. doi: 10.1016/j.conbuildmat.2017.04.154

Khalaf, A., Moayad, N., and Yousif, H. A. (1984). Use of rice husk ash in concrete. Int. J. Cement Compo. Lightweight Concrete 6, 241-248. doi: 10.1016/0262-5075(84)90019-8

Liu, F., Wang, J., Qian, X., and Hollingsworth, J. (2017). Internal curing of high performance concrete using cenospheres. Cem. Concr. Res. 95, 39-46. doi: 10.1016/j.cemconres.2017.02.023

Lura, P., Bentz, D. P., Lange, D. A., Kovler, K., and Bentur, A. (2004). "Pumice aggregates for internal water curing," in Proceedings of International RILEM Symposium on Concrete Science and Engineering: A Tribute to Arnon Bentur. Evanston, IL: RILEM Publications SARL, 22-24. doi: 10.1617/2912143586.013

Malhotra, V. M., and Mehta, P. K. (1996). Pozzolanic and Cementitious Materials. Advances in Concrete Technology. Canada: Gordon and Breach Publication,.

Mechtcherine, V., and Reinhardt, H.-W. (2012). Application of Super Absorbent Polymers (SAP) in Concrete Construction: State-of-the-Art Report Prepared By Technical Committee 225-SAP. Springer Science and Business Media. doi: 10.1007/978-94-007-2733-5

Metha, P. K., and Pitt, N. (1976). Energy and industrial materials from crop residues. Res. Recov. Conserv. 2, 23-38. doi: 10.1016/0304-3967(76) 90015-9

Möser, B., Pfeifer, C., Gerlicher, T., Heinz, D., Mechtcherine, V., and Dudziak, L. (2010). Investigations on the workability and microstructure development of UHPC; Part 2: influence of admixtures and curing on the microstructure of ultra-high strength concretes. Cem. Int. 8, 74-85.

Nguyen, V. T. (2011). Rice husk ash as a mineral admixture for ultra high performance concrete. Delft University, The Netherlands.

Okutani, T. (2009). Utilization of silica in rice hulls as raw materials for silicon semiconductors. J. Metals Mater. Miner. 19, 51-59. Available online at: http:// ojs.materialsconnex.com/index.php/jmmm/issue/view/32

Onojah, A., Amah, A. N., and Ayomanor, B. O. (2012). Comparative studies of silicon from rice husk ash and natural quartz. Am. J. Sci. Indus. Res. 3, 146-149. doi: 10.5251/ajsir.2012.3.3.146.149

Philleo, R. E. (1991). Concrete science and reality. Mater. Sci. Concr. II 1991, 1-8.

Rama Rao, G. V., and Seshagiri Rao, M. V. (2003). High performance concrete with rice husk ash as mineral admixture. Indian Concrete Insti. J. 17-21.

Ramasamy, V. (2011). Compressive strength and durability properties of rice husk ash concrete. KSCE J. Civil Eng. 16, 93-102. doi: 10.1007/s12205-0120779-2
Rodriguez de Sensale, G. (2006). Strength development of concrete with rice-husk ash. Cem. Conc. Comp. 28, 158-160. doi: 10.1016/j.cemconcomp.2005.09.005

Salman, A., Shahzada, K., Fahad, M., and Ashraf, M. (2014). Assessment of early-age autogenous shrinkage strains in concrete using bentonite clay as internal curing technique. Constr. Build. Mater. 66, 403-409. doi: 10.1016/j.conbuildmat.2014.05.051

Sensale, G. R. D., Ribeiro, A. B., and Gonçalves, A. (2008). Effects of RHA on autogenous shrinkage of Portland cement pastes. Cem. Concr. Compos. 30, 892-897. doi: 10.1016/j.cemconcomp.2008.06.014

Suryana, R., Iriani, Y., Nurosyid, F., and Fasquelle, D. (2018). Characteristics of silica rice husk ash from Mojogedang Karanganyar Indonesia. IOP Conf. Series 367:012008. doi: 10.1088/1757-899X/367/1/012008

Tuan, N. V., Ye, G., and Breugel, K. V. (2010). "Internal curing of ultra high performance concrete by using rice husk ash," in International RILEM Conference on Material Science - MATSCI, Aachen 2010. Vol. III (Aachen: AdIPoC), 265-274.

Viet-Thien-An, V., Roessler, C., Danh-Dai, B., and Ludwig, H.-M. (2014). Rice husk ash as both pozzolanic admixture and internal curing agent in ultra-high performance concrete. Cem. Concr. Compos. 53, 270-278. doi: 10.1016/j.cemconcomp.2014.07.015

Waheed, K., Shehzada, K., Tayyaba, B., Shams, I., and Sajjad, W. K. (2018). Performance evaluation of Khyber Pakhtunkhwa Rice Husk Ash (RHA) in improving mechanical behavior of cement. Constr. Build. Mater. 176, 89-102. doi: 10.1016/j.conbuildmat.2018.04.213

Wang, K., Jansen, D. C., Shah, S. P., and Karr, A. F. (1997). Permeability study of cracked concrete. Cem. Concr. Res. 27, 381-393. doi: 10.1016/S0008-8846(97)00031-8

Wyrzykowski, M., Ghourchian, S., Sinthupinyo, S., Chitvoranund, N., Chintana, T., and Lura, P. (2016). Internal curing of high performance mortars with bottom ash. Cem. Concr. Compos. 71, 1-9. doi: 10.1016/j.cemconcomp.2016.04.009

Ye, H. (2003). Superabsorbent polymer as self-curing admixture in cement-based materials. J. South China Univ. Technol. 31, 41-44. Available online at: http://caod.oriprobe.com/articles/6735021/Superabsorbent_Polymer_as_Self_ curing_Admixture_in_Cement_based_Materi.htm

Zhang, M. H., Lastra, R., and Malhotra, V. M. (1996). Rice-husk ash paste and concrete: some aspects of hydration and the microstructure of the interfacial zone between the aggregate and paste. Cem. Conc. Res. 26, 963-977. doi: 10.1016/0008-8846(96)00061-0

Zhang, M. H., and Malhotra, V. M. (1996). High-performance concrete incorporating RHA as a supplementary cementing material. ACI Mater. J. 93, 629-636. doi: 10.14359/9870

Zhang, M. H., Tam, C. T., and Leow, M. P. (2003). Effect of water-to-cementitious materials ratio and silica fume on the autogenous shrinkage of concrete. Cem. Concr. Res. 33, 1687-1694. doi: 10.1016/S0008-8846(03)00149-2

Zhengwu, J., Sun, Z., and Wang, P. (2005). Autogenous relative humidity change and autogenous shrinkage of high-performance cement pastes. Cem. Concr. Res. 35, 1539-1545. doi: 10.1016/j.cemconres.2004.06.028

Zhutovsky, S., Kovler, K., and Bentur, A. (2002). Efficiency of lightweight aggregates for internal curing of high strength concrete to eliminate autogenous shrinkage. Mater. Struct. 35, 97-101. doi: 10.1007/BF02482108

Conflict of Interest Statement: The authors declare that the research was conducted in the absence of any commercial or financial relationships that could be construed as a potential conflict of interest.

Copyright (c) 2019 Amin, Hissan, Shahzada, Khan and Bibi. This is an open-access article distributed under the terms of the Creative Commons Attribution License (CC $B Y)$. The use, distribution or reproduction in other forums is permitted, provided the original author(s) and the copyright owner(s) are credited and that the original publication in this journal is cited, in accordance with accepted academic practice. No use, distribution or reproduction is permitted which does not comply with these terms. 